\title{
Determinants of knowledge and perception of probiotic by Jabodetabek college students
}

\author{
Pradito, I.Y., *Wardana, A.A., Lo, D., Waspodo, P. and Surono, I.S. \\ Food Technology Department, Faculty of Engineering, Bina Nusantara University, Jakarta, Indonesia \\ 11480
}

\author{
Article history: \\ Received: 25 March 2020 \\ Received in revised form: 15 \\ May 2020 \\ Accepted: 31 May 2020 \\ Available Online: 14 July \\ 2020
}

Keywords:

Probiotics,

Perception,

Knowledge

\section{DOI:}

https://doi.org/10.26656/fr.2017.4(5).133

\begin{abstract}
Beneficial effects provided by probiotic products may not necessarily influence the perception of college students. This research was aimed to evaluate the relationship among the college student's knowledge, experience, perception, and purchase intension of probiotics among the Jabodetabek (Jakarta, Bogor, Depok, Tangerang, Bekasi) college students. The questionnaire responses from 200 participants with diverse demographic backgrounds were collected. The results showed that the average score on the probiotic knowledge and perception was good. According to chi-square test, there was no correlation among all variables of demographic on probiotic knowledge and experience. Furthermore, only respondent's experience played a role in their perception of probiotics ( $\mathrm{p}$ value $=0.00$ ) which was correlated to purchase intention indicated by $\mathrm{p}$ value $=0.00$.
\end{abstract}

\section{Introduction}

Functional foods, in recent years, have gained a big attention due to their benefits in preventing various health problems and improving certain physiological functions. Probiotic is a kind of functional food products which has been widely known and accepted by consumers. Probiotic is defined as beneficial living microorganisms which provide various health functions to the host by improving intestinal microbial balance (Salminen et al., 1999; Levin. 2011). Several health benefits were provided by probiotic such as overcoming the problem of intestinal infections, controlling pathogenic bacteria in the digestive tract, stimulating the immune system, and reducing cholesterol and LDL levels (Sudha et al., 2009; Surono. 2016).

Global probiotics market size is estimated reach \$ 57.4 billion by 2022 , growing at $7.7 \%$ of compound annual growth rate (CAGR) during 2016-2022 (Verma, 2016). Industrial demand augmentation might be associated with the consumer's awareness on potential benefits of probiotic strains. In Indonesia, Yakult annual report (2018) estimated that probiotic consumption reached 5.294 thousands of bottles/day. Probiotic investigations in Indonesia are relatively modest, largely focused on indigenous traditional food such as Dadih, traditional fermented buffalo milk originated from Padang, West Sumatera.
Many beneficial effects of the probiotic based product do not necessarily make that consumer realize these products. Even, there are many consumers who are still unable to identify probiotic foods (Al-Nabulsi et al., 2014). That poor awareness probably results in under consumption of probiotic products. Stanczak and Heuberger (2009) reported that lack of knowledge and awareness of probiotic was associated with the low probiotic consumption. There are few reports that have concerned on consumers' perception and factors affecting probiotic consumption, and probably no such works have been done in Indonesia particularly by college student respondents. Knowledge about object, scene, or event largely could not affect perception which is autonomously related to thought. However, visual experience on knowledge is able to influence perception in various ways (Rock. 1985). Hence, in this study, we examine the relationship among the college student's knowledge, experience, perception and purchase intension of probiotics among the Jabodetabek college students.

\section{Materials and methods}

\subsection{Data collection and analysis}

A questionnaire was used in this study to collect participant's data by using google form. A total of 200 respondents were gathered. Each survey participant was provided incentives from the research grant supported by DuPont Nutrition and Biosciences. Participants consisted eISSN: 2550-2166 / C 2020 The Authors. Published by Rynnye Lyan Resources 
of various ages of any gender, educational levels and majors, and socioeconomic status (Table 1). The inclusion criteria required enrolled college students located in Jabodetabek area excluded based on health status. The students, upon following self-administered questionnaire in regards to demographic characteristics, were requested to complete several questions consisting of three parts: knowledge, experience, and perception on probiotics.

Chi-square test was utilized to determine the association among the demographic variables on probiotic knowledge and experience. Linear regression was used to evaluate the relationships of understanding and experience parameters on perception, followed by correlation of perception on purchase intention.

\subsection{Ethical consideration}

This study, which was non-invasive, did not involve vulnerable population. The initial agreement was conducted by each respondent who was fulfilling the criteria and willing to participate. All information of the participants was kept in pure confidentiality.

\section{Results and discussion}

\subsection{Knowledge of probiotics}

Most of the college students knew basic knowledge well about probiotics with the exception of the recommended daily dose of probiotics, where $92.5 \%$ of students selected the wrong answer showed in Table 2. Those results were in agreement with a study conducted by Kolady et al. (2018) about awareness and use of probiotics among the millennials in the United States as well as by Mejia et al. (2019) about knowledge of probiotic foods of selected students in Laguna, Philippines. However, the opposite result was reported by another work that college students in Jordan had poor knowledge of probiotics although their awareness and acceptance of functional food and natural health products were increased (Al-Nabulsi et al., 2014). Moreover, they received information of probiotics mostly from social media or internet $(45.3 \%)$, followed by product advertisements $(29.6 \%)$, product sales $(14.4 \%)$, and books (13.4\%). This result is in accordance with Casey (2017) study that over 20 hours were spent by young generations on social media. It could be inferred that the most effective platform to transfer information about probiotics to university students is by social media or the

Table 1. Demographic characteristic and its correlation on probiotic knowledge and experience

\begin{tabular}{|c|c|c|c|c|}
\hline Variables & Categories & Population (\%) & $\begin{array}{c}\text { p-value on probiotic } \\
\text { knowledge }\end{array}$ & $\begin{array}{c}\mathrm{p} \text {-value on probiotic } \\
\text { experience }\end{array}$ \\
\hline \multirow{4}{*}{ Age group } & $<18$ years old & 0.5 & 0.46 & 0.46 \\
\hline & 18 - 20 years old & 19.4 & & \\
\hline & $21-23$ years old & 76.6 & & \\
\hline & $>23$ years old & 3.5 & & \\
\hline \multirow{4}{*}{ Educational level } & Vocational & 9 & 0.46 & 0.24 \\
\hline & Undergraduate & 88 & & \\
\hline & Master & 2 & & \\
\hline & Doctoral & 1 & & \\
\hline \multirow{2}{*}{ Gender } & Male & 65.7 & 0.99 & 0.37 \\
\hline & Female & 34.3 & & \\
\hline \multirow{4}{*}{ Monthly allowance } & $<$ Rp. 2.000 .000 & $70 \%$ & 0.45 & 0.29 \\
\hline & Rp. $2.000 .000-3.000 .000$ & $19 \%$ & & \\
\hline & Rp. $3.000 .000-4.000 .000$ & $6 \%$ & & \\
\hline & $>$ Rp. 4.000 .000 & $5 \%$ & & \\
\hline \multirow{5}{*}{ Domicile } & Jakarta & $35 \%$ & 0.38 & 0.5 \\
\hline & Depok & $7 \%$ & & \\
\hline & Bekasi & $4 \%$ & & \\
\hline & Bogor & $4 \%$ & & \\
\hline & Tangerang & $50 \%$ & & \\
\hline \multirow{8}{*}{$\begin{array}{l}\text { Educational } \\
\text { background }\end{array}$} & Natural sciences & $12 \%$ & 0.19 & 0.34 \\
\hline & Social-humanities & $14 \%$ & & \\
\hline & Engineering & $14 \%$ & & \\
\hline & Economics & $26 \%$ & & \\
\hline & Education & $3 \%$ & & \\
\hline & Art-design-media & $4 \%$ & & \\
\hline & Information system and technology & $8 \%$ & & \\
\hline & Health sciences & $19 \%$ & & \\
\hline
\end{tabular}


internet. Furthermore, based on chi-square test, there was no correlation among all variables on probiotic knowledge, showed in Table 1.

Table 2. Responses about knowledge of participants on probiotics

\begin{tabular}{lcc}
\hline Question & $\begin{array}{c}\text { Correct } \\
\text { response (\%) }\end{array}$ & $\begin{array}{c}\text { Incorrect } \\
\text { response (\%) }\end{array}$ \\
\hline What do probiotics contain? & 80.6 & 19.4 \\
$\begin{array}{l}\text { What is the source of probiotics? } \\
\begin{array}{l}\text { What is the recommended amount } \\
\text { of probiotic intake per day? }\end{array}\end{array}$ & 79.1 & 20.9 \\
$\begin{array}{l}\text { Probiotics can be found at? } \\
\begin{array}{l}\text { What is the advantage of } \\
\text { probiotics? }\end{array}\end{array}$ & 92 & 92.5 \\
$\begin{array}{l}\text { What is the main function of } \\
\text { probiotics? }\end{array}$ & 62.2 & 37.8 \\
\hline
\end{tabular}

\subsection{Experience on the consumption of probiotics food} products

Experience of participants on probiotic products showed that most of the students spent their money to buy a probiotic ranging from IDR $10.000-15.000$, in the type of drinks. Our results were similar to an earlier study that type of drinks such as yogurt and shake were the most preferred carriers of probiotics among the millennials compared to capsule form as the least preferred one (Kolady et al., 2018). Their probiotics consumption was recommended by their personal initiative, health consideration, irregular intake, with the last time consumption in less than 2 weeks. It confirmed the possibility that participants' willingness to try a probiotic product was influenced by health behaviour and their initiative more than by a health professional, food practitioner recommendation or the like. Moreover, most of them felt the benefit of probiotics, followed consumption instructions and storage method. As reported in some literature beforehand, our results were in line that, in general, participants read the food product labels before consuming probiotics (Siegrist et al., 2008; Kolady et al., 2018). Flavour, two brands, and social media were the most interesting about probiotic, the number of brands of probiotic products consumed and the best method to know probiotics respectively, confirmed by Table 3 . Furthermore, Table 4 shows that most of the university students had a good perception of probiotics $(73 \%)$, followed by $15 \%$ for the average category, and $12 \%$ for the bad perception. Furthermore, the correlation test using chi-square method revealed no correlation among all variables on probiotic experience. In addition, student's perception of probiotics showed in the good category ( $73 \%$ ) confirmed by Table 4 . Overall, these results offer insights for industry strategies in developing the outreach efforts for product development and marketing of probiotic products.
Table 3. Responses about respondent's experience toward consumption of probiotics food products

\begin{tabular}{|c|c|c|}
\hline Question & Answer & $\begin{array}{c}\text { Frequency } \\
(\%)\end{array}$ \\
\hline \multirow{4}{*}{$\begin{array}{l}\text { How much money did } \\
\text { you spend to buy a } \\
\text { probiotic? }\end{array}$} & $<$ IDR 10.000 & 27 \\
\hline & IDR $10.000-15.000$ & 39 \\
\hline & IDR $10.000-15.000$ & 19.5 \\
\hline & $>$ IDR 20.000 & 14.5 \\
\hline \multirow{4}{*}{$\begin{array}{l}\text { What kind of } \\
\text { probiotics did you } \\
\text { consume? }\end{array}$} & Drinks & 80 \\
\hline & Solid food & 13 \\
\hline & Powder & 5 \\
\hline & Supplement & 2 \\
\hline \multirow{4}{*}{$\begin{array}{l}\text { When did you } \\
\text { consume probiotics for } \\
\text { the last time? }\end{array}$} & $<2$ last weeks & 46.5 \\
\hline & 2-4 last weeks & 25 \\
\hline & $>4$ last weeks & 18.5 \\
\hline & $>6$ last weeks & 10 \\
\hline \multirow{4}{*}{$\begin{array}{l}\text { How often did you } \\
\text { take probiotics? }\end{array}$} & Every day & 9.5 \\
\hline & Not every day & 66 \\
\hline & Never & 5.5 \\
\hline & Lately never consume again & 19 \\
\hline \multirow{4}{*}{$\begin{array}{l}\text { Who was the person } \\
\text { who recommends } \\
\text { probiotics? }\end{array}$} & Personal initiative & 75.5 \\
\hline & Parents & 3.5 \\
\hline & Doctor & 8 \\
\hline & Friend & 13 \\
\hline \multirow{4}{*}{$\begin{array}{l}\text { What consideration did } \\
\text { you think of } \\
\text { consuming probiotics? }\end{array}$} & Flavour & 36.5 \\
\hline & Price & 1.5 \\
\hline & Health & 59 \\
\hline & Given by friend & 3 \\
\hline \multirow{2}{*}{$\begin{array}{l}\text { Did you feel the } \\
\text { benefit of probiotics? }\end{array}$} & Yes & 85 \\
\hline & No & 15 \\
\hline \multirow{2}{*}{$\begin{array}{l}\text { Did you follow the } \\
\text { instructions when } \\
\text { consuming it? }\end{array}$} & Yes & 60 \\
\hline & No & 40 \\
\hline \multirow{2}{*}{$\begin{array}{l}\text { Did you follow the } \\
\text { storage method as } \\
\text { instructed? }\end{array}$} & Yes & 88.5 \\
\hline & No & 11.5 \\
\hline \multirow{4}{*}{$\begin{array}{l}\text { How many brands of } \\
\text { probiotic products did } \\
\text { you consumed? }\end{array}$} & 1 & 27.5 \\
\hline & 2 & 46.5 \\
\hline & 3 & 12.5 \\
\hline & 4 or more & 13.5 \\
\hline \multirow{4}{*}{$\begin{array}{l}\text { What was the most } \\
\text { interesting about } \\
\text { probiotics? }\end{array}$} & Packaging & 36.5 \\
\hline & Advertisement & 5.5 \\
\hline & Benefit & 6.5 \\
\hline & Flavour & 51.5 \\
\hline \multirow{4}{*}{$\begin{array}{l}\text { What was the best } \\
\text { method to know } \\
\text { probiotics? }\end{array}$} & Social media & 54.5 \\
\hline & Television & 1 \\
\hline & Magazine & 38 \\
\hline & Seminar & 6.5 \\
\hline
\end{tabular}

Table 4. Responses on the perception of probiotics

\begin{tabular}{lcc}
\hline Categories & Score Intervals & Population $(\%)$ \\
\hline Bad & $1 \leq$ score $\leq 5$ & 12 \\
Average & $6 \leq$ score $\leq 10$ & 15 \\
Good & $11 \leq$ score $\leq 15$ & 73 \\
\hline
\end{tabular}


3.3 Participants' knowledge, experience toward perception and purchase intention of probiotic food products

Table 5 indicates that experience parameter was correlated to consumer perception, and consumer perception influenced purchase intention of university students indicated by its p-value. It could be inferred, their experience in consuming probiotics was more associated with their perception compared to their knowledge. That data revealed that there was a tendency not to need for further education of the Jabodetabek university student in regards to the understanding of probiotics such as definition, sources, benefits and function of probiotics. Similarly, Pferdekämper (2003) studied that the acceptance of functional foods was correlated on health consciousness and preventative health behaviour, while were not correlated on product knowledge. However, Bilgiç and Yüksel (2012) investigated that 114/149 participants had no sufficient knowledge about functional foods like probiotic which was the main consumer's reason for not consuming probiotic products. The previous study by Jong et al. (2003) also revealed a different finding that the consumption of product contained lactic acid bacteria such as yoghurt was dominated by participants who had good knowledge. Insignificant correlation showed that there were factors influencing respondent's knowledge on probiotic perception impacting on consumer consumption which need a further study. Furthermore, the impact of participant's perception could influence their willingness to consume probiotic products indicated by a significant value between perception and purchase intention parameters. The previous report stated that in the terms of functional food purchasing and consuming, several factors could be considered by the consumers including price, presentation of the food and the sensory attributes of the products (Barrios et al., 2008; Christidis et al., 2011). Tomic and Cerjak (2014) reported that product availability, taste and price-quality ratio contributed to purchasing and consuming functional food by young adult Croatian student, not according to the level of their knowledge and awareness.

Table 5. Correlation of knowledge, experience on perception and perception on purchase intention

\begin{tabular}{lcc}
\hline Variables & $\begin{array}{c}\text { Perception } \\
(\mathrm{p} \text {-value })\end{array}$ & $\begin{array}{c}\text { Purchase intention } \\
(\mathrm{p} \text {-value })\end{array}$ \\
\hline Probiotic knowledge & 0.21 & - \\
Probiotic experience & 0 & - \\
Probiotic perception & - & 0 \\
\hline
\end{tabular}

\section{Conclusion}

In this study conducted in Jabodetabek, perception and factors affecting probiotic consumption was observed in the college students from various age groups, educational levels, genders, monthly allowances, domiciles, and educational backgrounds. The variables were not correlated with probiotic knowledge and experience. Finally, the only experience on probiotics of the students was correlated to their perception, not for knowledge, which was able to affect their willingness in purchasing probiotic.

\section{Conflict of interest}

The authors declare no conflict of interest.

\section{Acknowledgments}

The authors acknowledge the financial support from DuPont Nutrition and Biosciences for conducting this research.

\section{References}

Al-Nabulsi, A.A., Obiedat, B., Ali, R., Osaili, T.M., Bawadi, H., Abushelaibi, A., Shaker, R.R. and Holley, R.A. (2014). Knowledge of probiotics and factors affecting their consumption by Jordanian College students. International Journal of Probiotics and Prebiotics, 9(3), 77-86.

Barrios, E.X., Bayarri, S., Carbonell, I., Izquierdo, L. and Costell, E. (2008). Consumer attitudes and opinions toward functional foods: A focus group study. Journal of Sensory Studies, 23(4), 514-525. https:// doi.org/10.1111/j.1745-459X.2008.00169.x

Bilgiç, S. and Yüksel, A. (2012). University students' perception and attitudes towards functional Foods in Istanbul, presented at the 2012 International Conference on Industrial Engineering and Operations Management, 2012. Istanbul, Turkey.

Casey, S. (2017). 2016 Nielsen Social Media Report. Retrieved on July 31, 2019, from Nielsen Website: https://www.nielsen.com/us/en/insights/ report/2017/2016-nielsen-social-media-report/

Christidis, Tsoulfa, N., Varagunam, G., Babatzimopoulou, M. and Maria. (2011). Cross sectional study of consumer awareness of functional foods in Thessaloniki, Greece. Nutrition and Food Science, 41(3), 165-174. https:// doi.org/10.1108/00346651111132439

Jong, N.D., Ocke, M.C., Branderhorst, H.A. and Friele, R. (2003). Demographic and lifestyle characteristics of functional food consumers and dietary supplement users. British Journal of Nutrition, 89(2), 273-281. https://doi.org/10.1079/BJN2002772

Kolady, D.E., Kattelmann, K., Vukovich, C. and Scaria, J. (2018). Awareness and use of probiotics among 
the millennials in the United States: Drivers and implications. Functional Foods in Health and Disease, 8(10), 505-518. https://doi.org/10.31989/ ffhd.v8i10.536

Levin, R. (2011). Probiotics-The road map. International Journal of Probiotics and Prebiotics, 6, 133-140.

Mejia, W.B., Barrion, A.S.A., Abacan, S.F. and Israel, K.A.T. (2019). Knowledge and consumption of probiotic foods of selected students in laguna, Philippines. EC Nutrition, 14(5), 452-459.

Pferdekämper, T. (2003). Determinants of the acceptance of functional food using an example of new probiotic rusk - an empirical analysis, presented at Consumer Perceptions of Healthiness of Food and Consumer Acceptance of New Foods, 2003. Middelfart, Denmark.

Rock, I. (1985). Perception and knowledge. Acta Psychologica, 59(1), 3-22. https:// doi.org/10.1016/0001-6918(85)90039-3

Salminen, S., Ouwehand, A.G., Benno, Y. and Lee, Y.K. (1999). Probiotics: how should they be defined? Trends in Food Science and Technology, 10(3), 107110. https://doi.org/10.1016/S0924-2244(99)00027-8

Siegrist, M., Stampfli, N. and Kastenholz, H. (2008). Consumers' willingness to buy functional foods. The influence of carrier, benefit and trust. Appetite, 51 (3), 526-529. https://doi.org/10.1016/ j.appet.2008.04.003

Stanczak, M. and Heuberger, R. (2009). Assessment of the knowledge and beliefs regarding probiotic use. American Journal of Health Education, 40(4), 207211. https:// doi.org/10.1080/19325037.2009.10599095

Sudha, M.R., Chauhan, P., Dixit, K., Babu, S. and Jamil, K. (2009). Probiotics as complementary therapy for hypercholesterolemia. Biology and Medicine, 1(4), 1 -13 .

Surono, I.S. (2016). Probiotik, Mikrobiome dan Pangan Fungsional. Yogyakarta: Budi Utama. [In Bahasa Indonesia].

Tomic, M. and Cerjak, M. (2014). Functional foods and the young. Journal of Food Products Marketing, 20 (5), 441-451. https:// doi.org/10.1080/10454446.2013.838535

Verma, P. (2016). Probiotics Market by Ingredient (Bacteria, and Yeast), Function (Regular, Preventative Healthcare, and Therapeutic), Application (Food and Beverages, Dietary Supplements, and Animal Feed), and End Use (Human Probiotics, and Animal Probiotics) - Global Opportunity Analysis and Industry Forecast, 20142022. Retrieved on April 30, 2020, from Allied
Market Research Website: https:// www.alliedmarketresearch.com/probiotics-market. 